\title{
Factor Influencing Job Involvement in Universiti Malaysia Perlis (UniMAP)
}

\author{
Suriani Sukri \\ School of Business Innovation and Technopreneurship, Universiti Malaysia Perlis (UniMAP) \\ Email: surianisukri@unimap.edu.my \\ Priyadharesheni Asogan \\ School of Business Innovation and Technopreneurship, Universiti Malaysia Perlis (UniMAP) \\ Email: priyaasogan@gmail.com \\ Waeibrorheem Waemustafa \\ School of Economic, Finance and Banking, Universiti Utara Malaysia \\ Email: waeibrorheem@uum.edu.my
}

Doi:10.5901/mjss.2015.v6n6s4p157

\begin{abstract}
This paper attempts to identify the relevant factors that create a massive collision on the job involvement at Universiti Malaysia Perlis (UniMAP). The sample of 110 was drawn from academic staff which are divided into categories of professor, associate professor, senior lecturer and lecturer. The results indicated that job involvement of UniMAP academic staffs is depends on the three dimension factor of job involvement in workplaces which are motivation, organizational citizenship behavior and job satisfaction. Among three factors tested in this study, UniMAP academic staff agreed that organizational citizenship behavior and job satisfaction influenced their job involvement. However, it is found that motivation has no significant relationship with job involvement of UniMAP academic staff.
\end{abstract}

Keywords: Job Involvement, Motivation, Organizational Citizenship Behavior and Job Satisfaction.

\section{Introduction}

Today's rapid changing organization environment and technology which could enforce potential employers and employees to better understand factors influencing job involvement in order to survive in their challenging workplace. In order to achieve the organization's goals, the great organization are built on the well-motivated and involvement of the human capital at the workplace. The level of employee's involvement and motivation will provide an excellent quality of their job which meets the organization's goals. Eventually, it will increase the performance of the organization as well as the employee's job performance. Therefore, the superior should give recognition to their employee for their involvement in the workplace. For example, the background of Malaysian education institutional issue has been raised especially in the university management. There are strong effects of job involvement and determinants that led towards the satisfaction of the academic lecturer as cited by Amzat \& Idris (2012). Furthermore, the government manages all the university through its policies and guidelines which could lead to an issue of minimal roles of the academic lecturer in the policy making procedure and also limited the decision making process of the academic lecturer's participation. There is less suggestion and ideas been heard from the academic lecturer for improvement. Therefore, the involvement of the academic lecturer has been an issue whereby they could be left out on-the-job activity and it affects the level of job involvement.

Job involvement has been clearly referred to absenteeism of the employees of an organization and intent to leave the organization as cited by Mohzan et. al., (2011). The researcher also has defined the job involvement that cause employee or an individual to spend more time which incur difficulties in filing the expectation of other roles in an organization. However, there is few study conducted on job involvement among academic staff in Malaysia.

Understanding the motivation is important at workplace in order to boost the output and job involvement of the workers. Lawrence \& Jordan (2009) defined that motivation can be split into specific and constant purpose system. Specific purpose mean a an individual who advisely feature an individual characteristic and significance their decisions and attribute whereby the constant purpose more to carry out the intuition response. It is clearly stated in the research 
that motivation of a workers carry the behavioral of them towards their job involvement and also it determine their level of motivation in the workplace. In some cases managers play an important role of leadership to boost their worker's motivation towards their performance and task that given to them. Motivation of a worker could provide better self enhancement towards their career. Research has shown that the more employee become motivated the more involvement towards their jobs at workplace.

In addition, organizational citizenship behavior has construct particular characteristic such as behavior that beyond formal prescribed by an individual's institution role, unrestricted attitude part of the employees which are not directly or explicitly reward the system and it is valuable for an persuasive and successful functioning for the public sector organizational stated by (Turnipseed, 1996).

Job satisfaction is an important element because it connected to raised absence and higher job turnover levels towards their job involvement at workplace by Droussiotis (2007). However, job satisfaction contributes to overall life satisfaction.

Based on these grounds the current study is conducted to address the following research questions:

1. What are the three dimension factors that contribute to the job involvement of UniMAP academic staff?

2. What is the relationship between those factor and job involvement of UniMAP academic staff?

3. How does those factor affect job involvement of UniMAP academic staff?

This study attempts to answer the research questions through the development of a research framework after investigating prior literatures in this context.

\section{Literature Review}

\subsection{Job Involvement}

Job involvement has been determined in a difference ways across studies and referred as activity of "central life interest", the significance of employee's job for his or her reputation, whereby an employee perform in his or her self-concept or self-esteem which stated by (Boon et. al., 2007). Boon et. al., (2007) theorized that job involvement refer as a remarkable factor in shaping up the motivation of an individual employee. Moreover, study conducted on the effects of job involvement among criminal justice employees has been limited to the police force that found no statistically significant between job involvement and also job satisfaction.

Rotenberry \& Moberg (2007) defined that one whose job is an essential side of his or her self-interpretation which highly job involved an individual will put the outward significant work towards the success of an organizational objective and less likely to turnover.

Mohzan et. al., (2011) also stated that the job involvement refer as an essential of primary source of an organizational commitment, motivation and job satisfaction that influence employee's job performance. This show the employee being involved on enhancing the motivational process which turn individual job performance such as absenteeism and also turnover.

Moreover, employed undergraduates in the USA has examined the connection between job involvement and organizational citizenship behavior by (Rotenberry \& Moberg, 2007). This show the collaborate validity of an employee's self-rated job involvement which refer to the main key term of organizational citizenship behavior such as altruism, civic virtue and conscientiousness on the effect of work centrality, personality, employee status such as full time versus part time and gender. Rotenberry \& Moberg (2007) disclose that job involvement has a collision on the employee performance which refers on measuring the job performance of current study both in-role job performance and extra-role organizational citizenship behavior. Rotenberry \& Moberg (2007) had examined an individual noted their full-time or parttime work rank that provide insufficient variability of the data for the variables.

Cortis \& Cassar (2005) found that employee captivate themselves regarding their job but involving as the central part of their lives. Female managers who has work path and offspring align at detriment because have the offspring demand which meddling with the women's career, lead them to do overtime, reorganize their working hours on additional work assignment also compromise the circumstance of less involving than the male counterparts. Cortis \& Cassar (2005) also has argued that the employees which job involved more probable to rely on their work virtue also exhibit the progress obligation which reinforce the individual within an organizational. For example, the concept of job involvement has searched extensively by an organizational research that been explored to the work experiences and job attitudes of personnel, which have high need for achievement and growth. 


\subsection{Motivation}

Densten, (2002) shows that motivation take place "when a need is stimulate and the individual desires to content it", therefore motivation is the core to the success of the organization is essential when the higher employee's levels of motivation, the more productive outcome they can give to the organization .

Mohzan et. al., (2011) motivation is the enthusiasm or want to do something, trained by the act or competence to content some demand has described the motivation as the willing where as Vignali (1997) has stated that an individual to expend or act in order to accomplish the organizational objective, trained by the act of competence to satisfy individual needs. Motivation is an important factor for the achievement of employee whereby increases the employee's job involvement. It also maintain individual to be more dynamic and improve their achievement at workplace.

Ayub \& Rafif (2011) motivation as the foundation of task that dominate employees to complete confident duty of their own free will, in order to reach the organization's goal and content their own requirement. Therefore, it is very important for employer to motivate their employee in order to increase the organization productivity as well as the profit. Ayub \& Rafif (2011) added that motivation has influenced by an employee innate such as people's own interests, value and want, such as task difference and duty and organizational characteristics such as its approach and duties. Despite that the researcher has described that motivation as within and extrinsic forces which inaugurate the work-related behavior and determine its form, intensity and duration.

Wong \& Heng (2009) classified motivation theory that owned by Abraham Maslow which is known as the hierarchical needs include of five basic level of needs of human being in their daily life. However, there are an alternative to Maslow theory has three level such as existence, relatedness and growth. For example, physiological factors known as the existence needs such as food, shelter, clothes, salary, reward and safety. Materiality wants known as the connection such as offspring, confidant, and work group. Last but not least self-actualization and self-esteem refer as the growth needs.

A study of motivation show that the impact on the academic lecturer motivation in a higher institute of education which refer to the cleanliness factor of Herzberg. The dissatisfaction could prosper from the frustration which able to prevent academic staff from accomplish their jobs such as indigent schedule organization, deficient conservation of educational furniture or else time management (Wong \& Heng, 2009).

\subsection{Organizational Citizenship Behavior}

Murphy, Athanasou \& King (2002) defined organizational citizenship behavior as the person attitude that is unrestricted which is not precisely that identify by the benefit system and also advocate persuasive functioning of the organization. Organizational citizenship behavior refers to employees such as auxiliary actions to assist other employee and go further stipulation of their duty.

Civic virtue as affective involvement of the institution of least required by the person's prompt job, sportsmanship refer as the liberal less than without unreasonable critism, altruism defined as help a person with institution compatible job, conscientiousness which means going further the least act necessity expected by the institution, courtesy refer of prohibit occurrence of job difficulty, cheerleading refer to reassuring others and pacific resolving dispute and maintain a preserve effort as stated by (Dimitriades, 2007).

The citizenship tendency inclined to maintain social relationship which could reduce the voice of employees and also give suggestion in order to improve existing methods. The task has highlight the importance of a difference align organizational citizenship behavior which mean improving the effectiveness of the social network which form to maintain the current relationship in the public sector among the employees (Sevi, 2010).

Moreover, organizational citizenship behavior has been related construct from the organizational commitment that developed by organizational psychologist emphasize to particular class of employee behavior and attitude based for a practically significant workplace based of employee job attitudes (Chughtai, 2008).

Hence, organizational citizenship behavior exist of factors such as positive and negative "extra-role" behavior which influence the employee's productivity believed to be reflected in performance evaluations (Turnispeed, 1996). The variable of job satisfaction has related to organizational citizenship behavior which affective response of various job related whereby explain the employee's mood engaged with their organizational citizenship behavior according researcher.

Organizational citizenship behavior is most important variable of explaining the individual as a social theory with greater frequency which means the organizations and their representatives make a better allocation decision making towards their job performance as described by Bogler \& Somech (2005). Teachers are professional staff in a public 
sector that works normatively by improving the student performance in their studies, from here the teachers have to be able face with their student discipline and aware with the student needs (Bogler \& Somech, 2005). Therefore, teacher exhibit the higher level of organizational citizenship behavior whenever they feel control of autonomy on their task whereby they experience the meaningfulness of their responsibility.

Kim (2006) has stated that organizational citizenship behavior manage the employee of a work unit whereby increase the work performance outcome, reduce the organization need in order to scarce the resources to simple functions and also improve the capability of employees to carry out their jobs by for more capable in planning, scheduling and problem solving.

Turnipseed (1996) mentioned organizational citizenship behavior has become an important element of a cognitive appraisal of an employee work performance and also related to their work environment based on the outcome such as positive and negative behavior during perform their task in an organization. Employee with positive behavior towards their organization they tend to be more spiritual on handling their work.

Turnipseed (1996) also stated that organizational citizenship behavior has two main facets such as organizational altruistic. It refers to specify person and also organizational citizenship behavior compliance more of "good soldier" or "good citizen" of doing the "right and proper". Employee in working environment helps to attach them with the interrelated work relationship between other employees from different department and establish an altruistic motive with an organization share their skill, knowledge, capability, and experiences together with passion (Becton, Giles \& Schraeder, 2008).

\subsection{Job Satisfaction}

Job satisfaction defined as the feature of growth in an institution which valuable for the superior to comprehend the constituent of the job and assure that the workplace provides the academic lecturer requirements (Droussiotis, 2007). Job satisfaction is an intuition response to their job which resulting from the obligatory's contrasting of substantial consequence with those aspiration (Lim \& Ling, 2012).

Ayub \& Rafif (2011) job satisfaction disclose to an individual's own judgment of their jobs opposite of those concern that are valuable to them" and a person's satisfied when they are feeling pleasant about their jobs and relates towards their doing their jobs well or else being acknowledged in the institution.

Job satisfaction attributes the decisive and adverse feelings and behaviour of an individual hold about their work and that not only rely upon their work but also on personal characteristic such as age, gender, health and family (Ayub \& Rafif, 2011). Chimanikire et. al., (2007) stated that job satisfaction is one of the top concerns for administration and institution researchers have been regulate on dissimilar aspects of job satisfaction because it has been intently associated with the institution phenomena such as guidance, self-esteem, inspiration and accomplishment.

Ayub \& Rafif (2011) has revealed that the determinants which provide to the job satisfaction of the person are salary, job, colleagues and working condition. Other interpretation has measured that the job satisfaction on the basis of employee, behavior to the task, connection between the colleagues, organization's custom and platform, promotion and salary (Ayub \& Rafif, 2011).

According to Lee (2009) that a person feels satisfied when they closely related to their labor market such as output, quits and absence. Kazi \& Zadeh (2011) has revealed that the job satisfaction as the person biased by valuation of different dimension of the person's involvement. It is a enjoyable affecting state resulting from the assessment of a person's task whereby cognition and an individual of expand the concept of appointing the appropriate way for it is strangling. However, it not only linked to the psychological attitude of the person but also related to biological attitude depending on their identify characteristic.

Tsai (2008) identified that the job satisfaction of an employee rely on the result been collected from the interpretation of individual's job characteristics. The task is based upon by the reference structural definition whereby certain of the employee situation affect their satisfaction during their work been carried out at workplace. It is depend on the factors such as comparison between jobs and comparison with the others employee working experiences, skill and ability of accomplishing their organization objective.

Employees' psychological recognition given through their accomplishment of their job to achieve the level of job satisfaction decide by the difference of the task actually and expected obtained by the employees. There are five determinants that related to the job satisfaction of the employees included company policy, administration, inter-personal relations, work condition and payment (Tsai, 2008).

Brunetto \& Wharton (2002) referred job satisfaction as the employee's gaining their success and enjoyment from their won effort in the workplace and given the proper recognition for their hardship. For example, when an employee has 
a pessimistic behavior towards their job, they have high level of job satisfaction and identify their goals in the organization. However, Brunetto \& Wharton (2002) has stated that an employee could be able adopt their beliefs towards the management, they will tend to cooperate with the management goals and objectives, such employee are likely to be attached emotionally with the organizational and has strong level of job satisfaction. An employee tend to be more loyal towards their organization when they have the high level of job satisfaction whereby the employee has happy working environment with the other employee, who share the experience and skill together. The bonding of the employee working relationship could foster the level job satisfaction in the workplace.

\section{Research Methodology}

This study employs empirical analysis to determine the relationship between job involvement variables, which consisted of motivation, organizational citizenship behavior and job satisfaction. Job involvement are tested in the questionnaires and respondents were asked to rate on scale of 1 to 5, 1 denotes "strongly disagree" and 5 reflects "Strongly Agree" on these factor with respect to add knowledge about the factor that contributes to the job involvement of UniMAP academic staff. Three job involvement factors are analyzed by using The Statistical Package for Social Sciences (SPSS 18.0) software.

\section{Theoretical Framework and Hypotheses}

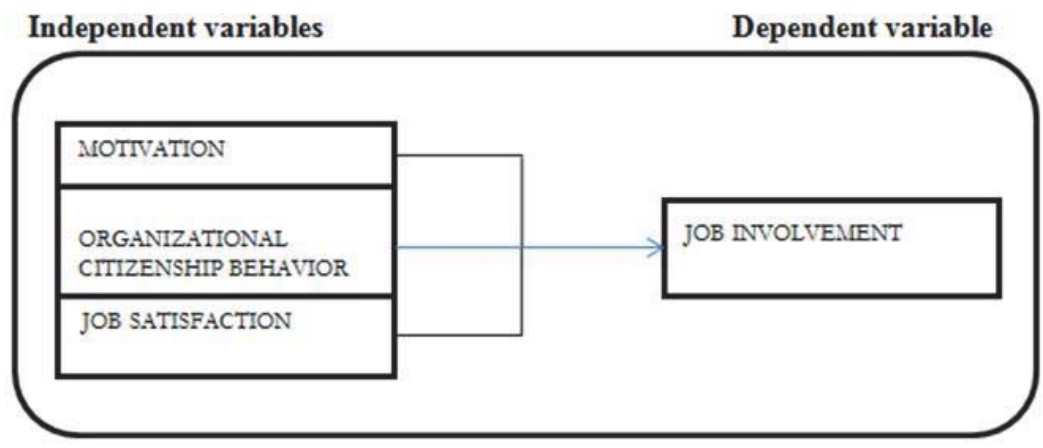

Figure 1: Theoretical framework

Hypothesis 1: Is there any relationship between motivation and job involvement of UniMAP academic staff? staff.

$\mathrm{H}_{0}$ : There is no significant relationship between between motivation and job involvement of UniMAP academic

$\mathrm{H}_{1 \mathrm{a}}$ : There is a significant relationship between between motivation and job involvement of UniMAP academic staff.

Hypothesis 2: Is there any relationship between organizational citizenship behavior and job involvement of UniMAP academic staff?

$\mathrm{H}_{0}$ : There is no significant relationship between organizational citizenship behavior and job involvement of UniMAP academic staff.

$\mathrm{H}_{1 a}$ : There is a significant relationship between organizational citizenship behavior and job involvement of UniMAP academic staff.

Hypothesis 3: Is there any relationship between job satisfaction and job involvement of UniMAP academic staff?

$\mathrm{H}_{0}$ : There is no significant relationship between job satisfaction and job involvement of UniMAP academic staff.

$\mathrm{H}_{1 \mathrm{a}}$ : There is a significant relationship between job satisfaction and job involvement of UniMAP academic staff. 


\section{Findings}

Table 1: Demographic Profile of Respondent.

\begin{tabular}{|c|c|c|c|}
\hline Variables & Categories & Frequency & Percentage (\%) \\
\hline Gender & $\begin{array}{l}\text { Male } \\
\text { Female }\end{array}$ & $\begin{array}{l}55 \\
55\end{array}$ & $\begin{array}{l}50.0 \\
50.0\end{array}$ \\
\hline Race & \begin{tabular}{|l} 
Malay \\
Chinese \\
Indian \\
Others
\end{tabular} & $\begin{array}{c}103 \\
5 \\
2 \\
0\end{array}$ & $\begin{array}{c}93.6 \\
4.5 \\
1.8 \\
0\end{array}$ \\
\hline Age & $\begin{array}{l}20-29 \text { years } \\
30-39 \text { years } \\
40-49 \text { years } \\
50-59 \text { years } \\
>60 \text { years }\end{array}$ & $\begin{array}{c}26 \\
69 \\
12 \\
2 \\
1\end{array}$ & $\begin{array}{c}23.6 \\
62.7 \\
10.9 \\
1.8 \\
0.90\end{array}$ \\
\hline Marital status & $\begin{array}{l}\text { Single } \\
\text { Married } \\
\text { Divorced }\end{array}$ & $\begin{array}{c}22 \\
87 \\
1\end{array}$ & $\begin{array}{l}20.0 \\
79.1 \\
0.90\end{array}$ \\
\hline Nationality & \begin{tabular}{|l} 
Malaysian \\
Non-Malaysian
\end{tabular} & $\begin{array}{c}109 \\
1\end{array}$ & $\begin{array}{l}99.1 \\
0.90\end{array}$ \\
\hline Position & $\begin{array}{l}\text { Professor } \\
\text { Associate Professor } \\
\text { Senior Lecturer } \\
\text { Lecturer }\end{array}$ & $\begin{array}{c}1 \\
3 \\
19 \\
86\end{array}$ & $\begin{array}{c}0.90 \\
2.7 \\
17.3 \\
78.2\end{array}$ \\
\hline Administration work & $\begin{array}{l}\text { Do not hold any administration work } \\
\text { Teaching Engineering } \\
\text { Deputy Dean (Academic and Research) } \\
\text { Subject Coordinator } \\
\text { Coordinate Programmes } \\
\text { Program Chairman } \\
\text { Program Chairperson Postgraduate }\end{array}$ & $\begin{array}{c}102 \\
1 \\
1 \\
1 \\
1 \\
1 \\
2\end{array}$ & $\begin{array}{l}92.7 \\
0.90 \\
0.90 \\
0.90 \\
0.90 \\
0.90 \\
1.8\end{array}$ \\
\hline Department & $\begin{array}{l}\text { School of Mechatronic Engineering } \\
\text { School of Bioprocess Engineering } \\
\text { School of Environmental Engineering } \\
\text { School of Manufacturing Engineering } \\
\text { School of Electric Engineering } \\
\text { School of Material Engineering } \\
\text { School of Microelectronic Engineering } \\
\text { School of Computer and Engineering } \\
\text { School of Business Innovation and Technopreneurship } \\
\text { PTKPI } \\
\text { IMK }\end{array}$ & $\begin{array}{l}10 \\
10 \\
10 \\
10 \\
10 \\
10 \\
10 \\
10 \\
10 \\
\\
10 \\
10\end{array}$ & $\begin{array}{l}9.1 \\
9.1 \\
9.1 \\
9.1 \\
9.1 \\
9.1 \\
9.1 \\
9.1 \\
9.1 \\
9.1 \\
9.1\end{array}$ \\
\hline
\end{tabular}

Table 1 shows the summarization of the demographics data collected that consist of respondents' gender, race, age and religion. It shows that the number of male and female respondents is equal, both 55 and resulted $50 \%$ of the respondents are male, and 50\% are female. The majority of the respondents are Malay (93.6\%), Chinese (4.5\%), and Indian (1.8\%) and for other is $0 \%$. While for the age, majority respondents are aged between $30-39$ years old (62.7\%), followed by aged between $20-29$ years old (23.6\%) , 40-49 years old (10.9\%), 50-59 years old (1.8\%) and last $>60$ years old $(0.9 \%)$. As for position, out of 110 respondents, $78.2 \%$ of respondents are lecturer, $17.3 \%$ are senior lecturer , $2.7 \%$ are associate professor and $0.9 \%$ are professor. 


\section{Reliability Analysis}

Table 2: Results of Reliability Test

\begin{tabular}{|l|c|c|c|c|}
\hline Variables & Number of Items & Items dropped & Items recorded & Cronbach Alpha \\
\hline Job Involvement & 10 & - & - & 0.785 \\
\hline Motivation & 10 & - & - & 0.697 \\
\hline Organizational Citizenship Behaviour & 10 & - & - & 0.757 \\
\hline Job Satisfaction & 10 & - & - & 0.717 \\
\hline
\end{tabular}

The Cronbach Coefficients Alpha value for all the factors ranged from .697 to .785 which indicated the good inter-item consistency for the each other factor that involved in this study. Sekaran (2010) that the reliability analysis of a measurement based on the consistency and stability of the data collected. So, the reliability analysis is shown for a better measurement of data collected. As mentioned by Sekaran (2010) that this will ensure that the all the items used in each of the variables are free from the error and given a consistency results.

\section{Descriptive Analysis among All Variables}

Table 3: Descriptive Analysis

\begin{tabular}{|l|c|c|c|c|c|}
\hline Factors & Mean & Standard Deviation & Min & Max & Variance \\
\hline Job Involvement & 3.8591 & 0.43899 & 2.80 & 5.00 & 0.193 \\
\hline Motivation & 3.3955 & 0.44006 & 2.50 & 5.00 & 0.194 \\
\hline Organizational Citizenship Behaviour & 3.7127 & 0.38459 & 2.80 & 5.00 & 0.148 \\
\hline Job Satisfaction & 3.5382 & 0.46432 & 1.90 & 4.00 & 0.216 \\
\hline
\end{tabular}

Table 3 shows the measurement of the dependent variable and independent variable. The mean for Job involvement carried out 3.8591, motivation was 3.3955, organizational citizenship behavior was 3.7127 and job satisfaction was 3.5382. The standard deviation of all the variables is $0.43899,0.44006,0.38459$ and 0.46432 . The highest mean is the job involvement which is 3.8591 and standard deviation of 0.43899 .

\section{Regression Assumption}

\subsection{Linearity}

Based on the normal P-P Plot of Regression Standardized Residual indicates that the distribution of residuals normal at every level of predicted $Y$ and constant in variance across the levels of the predicted $Y$. Figure 2 illustrates the linearity plot of each variable used in the study. The results indicate that not all of the variables pass the linearity characteristic.

\subsection{Multi Collinearity}

Table 4: Multi Collinearity

\begin{tabular}{|c|c|c|c|c|c|}
\hline Model & Standardized Coefficients & T & Sig. & Tolerance & VIF \\
\hline M & 0.135 & 1.438 & 0.1530 & 0.876 & 1.141 \\
\hline OCB & 0.213 & 2.083 & 0.040 & 0.739 & 1.353 \\
\hline JS & 0.205 & 2.040 & 0.044 & 0.770 & 1.299 \\
\hline
\end{tabular}

Table 4 shows the multi collinearity has shown that the unstandardized and standardized coefficient of all the variables. The unstandardized coefficients beta shown for motivation is 0.135 where else organizational citizenship behavior was 0.243 and job satisfaction was 0.193 . However, the standardized coefficients of motivation were 0.135 where else for the organizational citizenship behavior was 0.213 and job satisfaction was 0.205 . Therefore, the ratio of motivation was 1.438, organizational citizenship behavior was 2.083 and last but not least job satisfaction was 2.040 . The tolerance of the motivation is 0.876 where else the VIF is 1.141. Another independent variable is organizational citizenship behavior's 
tolerance is 0.739 and the VIF is 1.353 . Job satisfaction has its tolerance of 0.770 and VIF is 1.299 . Table 4 shows that VIF also show that thereis low multicollinearity among the variables (VIF $=1.141-1.353)$.

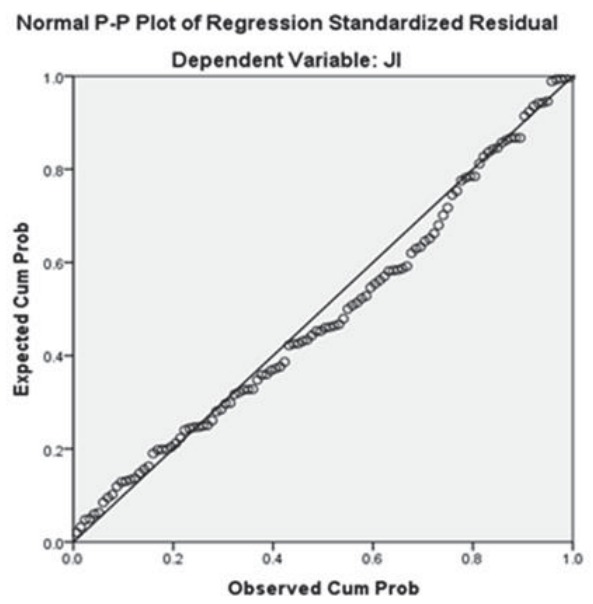

Figure 2: Normal P-P Plot of Regression Standardized Residual.

Table 5: Regression analysis for all the variables

\begin{tabular}{|l|c|c|c|}
\hline Variables & Standardized Coefficients & t-Statistic & Sig.Value \\
\hline Motivation & 0.135 & 1.438 & 0.153 \\
\hline Organizational Citizenship Behavior & 0.213 & 2.083 & 0.040 \\
\hline Job Satisfaction & 0.205 & 2.040 & 0.044 \\
\hline R square $=\mathbf{0 . 1 8 0}$ & & \\
Durbin Watson $=\mathbf{1 . 8 1 5}$ & & \\
$\mathrm{F}=\mathbf{7 . 7 3 6}$ & & \\
Sig.F $=\mathbf{0 . 0 0 0}$ & & \\
Condition Index $=\mathbf{2 7 . 7 8 8}$ & & \\
\hline
\end{tabular}

Based on the regression analysis, the findings showed that there is one variable that has no significant effect (sig.t > 0.05) on job involvement of UniMAP academic staff. The variable is Motivation (0.153). This finding is opposed to have a conclusive effect on the job involvement. Table 5 shows that organizational citizenship behavior $(0.040)$ and job satisfaction (0.044) has significant effect on job involvement of UniMAP academic staff. In addition, R square of the regression analysis has indicated $18 \%$. This statistical analysis suggests that the three independent variables explain only $18 \%$ variations in job involvement of UniMAP academic staff. This $\mathrm{R}$ square shows a weak relationship between independent variables and job involvement of UniMAP academic staff. Durbin Watson is 1.185. The condition index of the regression analysis is 27.788 .

Table 6: Siginificant of Coefficient Estimate

\begin{tabular}{|l|c|c|c|}
\hline Variables & \multicolumn{3}{|c|}{ Relationship between Independent Variables and Dependent Variables } \\
\hline Motivation (M) & $\left(^{+}\right.$ & M & \\
\hline Organizational Citizenship Behavior (OCB) & $\left(^{+}\right.$ & $\mathrm{OCB}$ & $\mathrm{Jl}$ \\
\hline Job Satisfaction (JS) & $\left(^{+}\right.$ & $\mathrm{JS}$ & $\mathrm{Jl}$ \\
\hline
\end{tabular}


Table 6 presents the relationship between motivation as independent variable and job involvement as dependent variables positively correlated. The result indicates that the coefficient estimated is positively correlated but not significantly related to job involvement.

The relationship between organizational citizenship behavior as independent variable and job involvement as dependent variables positively correlated. The result indicates that the coefficients estimated of organizational citizenship behavior is positively correlated and significantly related to the job involvement.

The relationship between job satisfaction as independent variable and job involvement as dependent variables positively correlated. The result indicates that the coefficients estimated of job satisfaction is positively correlated and significantly related to the job involvement.

Table 7: Correlation Matrix

\begin{tabular}{|c|c|c|c|c|}
\hline \multirow{3}{*}{$\begin{array}{c}\text { Pearson } \\
\text { JI }\end{array}$} & JI & M & OCB & JS \\
\cline { 2 - 5 } M & 1.000 & & & \\
\cline { 2 - 5 } OCB & 0.259 & 1.000 & & \\
\cline { 2 - 5 } JS & 0.353 & 0.328 & 1.000 & \\
\cline { 2 - 5 } & 0.339 & 0.265 & 0.465 & 1.000 \\
\hline
\end{tabular}

Table 7 shows the highest significant correlation matrix has shown 0.465 between the job satisfaction and organizational citizenship behavior. On the other hand, the lowest significant correlation is 0.259 between the motivation and job involvement. The correlation between organizational citizenship behavior and job involvement are 0.353 which mean it has high correlation with job involvement.

\section{Summary}

Table 8: Summary of Findings

\begin{tabular}{|c|l|c|}
\hline No of Hypothesis & Statement of Hypothesis & Results \\
\hline $\mathrm{H} 1$ & There is significant relationship between motivation and job involvement. & Rejected \\
\hline $\mathrm{H} 2$ & There is significant relationship between organizational citizenship behavior and job involvement. & Accepted \\
\hline $\mathrm{H} 3$ & There is significant relationship between job satisfaction and job involvement. & Accepted \\
\hline
\end{tabular}

\section{Discussion}

In this section will be discussed on the rejected hypothesis which is Hypotheses 1 which examined the connection between the motivation and job involvement. Sandra (2009) has argued that there are significant motivational drivers that could affect the employees' characteristics which of the incompetence need for achievement in an organizational. Employee who has perception that they been underpaid for their achievement which could reduce the level of job involvement.

Moreover, the negative mind set of employees could leave them with a bad impact on the organizational which will lead them into emotionally distressed. Constantly, this issue will decrease the level of motivation and job involvement of the employees to run the organizational. Hence, awareness of the organizational is needed on this kind of issue so that the employee's value will be appreciated in order to increase the employee's expectation at workplace.

Hypothesis 2 has examined the connection between organizational citizenship behavior and job involvement. This hypothesis has been accepted according to (Piercy, Lane \& Cravens, 2002) mentioned that enhancing the effectiveness which employee could go further on the role necessity of an organizational. The organizational concern on the behavior and activity may relate to the emergence of organizational citizenship behavior.

On the other hand, the organizational citizenship behavior has divided into positive and negative roles which could influence the employee's focus and reflected the job involvement of an employee. For employee who does has the concern on helping a new staff to familiarize with their work could make the new staff to feel high altruism towards the employee. The element of cheerleading has been used by the organizational that could bring more encouragement on giving hand on others for the task given.

Hypothesis 3 has been examined the connection between job satisfaction and job involvement. This hypothesis has been accepted because of personal job satisfaction that may satisfy with the work whereby the employee needs to 
balance social and career life together. Ghulam (2011) has argued that the work life is more to sense of enthusiasim when an individual experiences the work life balance. It is also stated that the ability of individual to maintain their level of demands at workplace.

\section{Implications of the Findings}

The results of the study has shown the factor of job involvement among the academic staff in UniMAP. This finding has been compiled with the factors that contribute towards motivation, organizational citizenship behavior and job satisfaction. It is important for an organization to find the right way to overcome these problem at workplace. Moreover, the organization need to acknowledge that job involvement as an important element in order to achieve organization's goals. Therefore, the higher management need to identify the problems arise in their organizational and solve it after consideration of all the consequences.

\section{Recommendation for Future Research}

There are three suggestions for further research. First, replicate this study at other public and private universities to allow for the comparison of results from different regions in Malaysia. Next, it would be of interest to incorporate samples of academic staffs from foreign universities to compare their job involvement in their workplaces. By involvement from other academic staffs, it can add to better understanding of job involvement among academic staff. Finally, additional research should continue to examine if any significant relationship between other job involvement factors to determine if any significant relationship exist.

\section{Limitations of the Study}

While conducting this study, there are numbers of limitations based on approach and design. First, the result of the findings may be biased and the sample that had been taken is limited to a selected institution which is UniMAP only. In addition, the respondents were based on only 110 respondents for this research, may not have reflected the overall population. The questionnaires were distributed randomly by the administrative staff. Most of the academic lecturer enclosed their own opinion on the questionnaires that been asked. The intention was to involve the respondents to answer the questions and reduce common response bias. Additionally, in the reliability analysis show the good reliable of the questions based on the consistency and stability of the data collected.

Second, the sample sizes of the respondent are limited to the UniMAP's academic staff which has influence on the both statistical analysis as well as the findings which based on the end result. Finally, this study is conducted using 3 factors only. Therefore, it is not good enough to rank the factors that influence the job involvement among academic staff because there are many other job involvement factors that should be tested to better understand the study.

\section{Conclusion}

The findings from this study shows that academic staffs job involvement factors are motivation, organizational citizenship behavior and job satisfaction. This finding implies that the academic staffs are more prefer the jobs that can provide them with a good organizational citizenship behavior with a level of job satisfaction in performing the job. The organizational citizenship behavior and job satisfaction is ranked as the most significant related to the academic staffs job involvement as compared to the motivation. Therefore, it can be concluded that academic staffs are more prefer jobs that have the feeling of belonging satisfaction in doing any job rather than motivation. Overall, academic staff improving themselves because their improvement will lead them to produce a quality students and also a good performer as employee in an organizations. Therefore, this will increase the human capital for the future national development programmes. This will also increase the level of job involvement of the academic staff, feel satisfy and worth working.

\section{References}

Amzat, I., H., \& Idris, A. R. (2012). Structural Equation Models of Management and Decision-Making Styles with Job Satisfaction of Academic Staff in Malaysian Research University. International Journal of Educational Management 26(7), 616 - 645.

Ayub, N., \& Rafif, S. (2011). The relationship between work motivation and job satisfaction. Pakistan Business Review, 13.

Becton, J. B., Giles, W. F., \& Schraeder, M. (2008). Evaluating and rewarding OCBs: Potential consequences of formally incorporating 
organisational citizenship behaviour in performance appraisal and reward systems. Employee Relations 30(5), 494 - 514.

Bogler, R., \& Somech, A. (2005). Organizational citizenship behavior in school: how does it relate to participation in decision making?. Journal of Educational Administration, 43(5), 420-438.

Boon, O. K., Arumugam, V., Safa, M. S. \& Bakar, N. A. (2007). HRM and TQM: Association with job involvement. Personnel Review 36(6), 939-962.

Brunetto, Y., \& Wharton, R. F. (2002). Using social identity theory to explain the job satisfaction of public sector employees. International Journal of Public Sector Management 15(7), 534 - 551.

Chimanikire, P., Mutandwa, E., Gadzirayi, C. T., Muzondo, N. \& Mutandwa, B. (2007). Factors affecting job satisfaction among academic professionals in tertiary institutions in Zimbabwe. African Journal of Business Management 1(6), 166-175.

Chughtai, A. A. (2008). Impact of job involvement on in-role job performance and organizational citizenship behavior. Journal of Behavioral and Applied Management, 9(2), 169-183.

Cortis, R., \& Cassar, V. (2005). Perceptions of and about women as managers: investigating job involvement, self-esteem and attitudes. Women in Management Review, 20(3), 149-164.

Densten, I. L. (2002). Clarifying Inspirational Motivation and Its Relationship to Extra Effort. Leadership and Organization Development Journal 23(1), 40-44.

Dimitriades, Z. S. (2007). The influence of service climate and job involvement on customer-oriented organizational citizenship behavior in Greek service organizations: A Survey. Employee Relations 29(5), 469 - 491.

Droussiotis, A. A., J. (2007). Job Satisfaction of Managers in Cyprus. EuroMed Journal of Business 2(2), $208-222$.

Kazi, G. M. Z., Z. F (2011). The Contribution of Individual Variables: Job Satisfaction and Job Turnover. Interdisciplinary Journal of Contemporary Research in Business 3(5).

Kim, S. (2006). Public Service Motivation and Organizational Citizenship Behavior in Korea. International Journal of Manpower 27(8), 722-740.

Lawrence, S., \& Jordan, P. (2009). Testing an Explicit and Implicit measure of Motivation. International Journal of Organizational Analysis 17(2), 103-120.

Lee, C. S. (2009). An Empirical Study of Employee Job Involvement and Personality Traits: The Case of Taiwan. Int. Journal of Economics and Management 3(1), 22-36.

Lim, L. J. W., \& Ling, F. Y. Y (2012). Human Resource Practices of Contractors that Lead to Job Satisfaction of Professional Staff. Engineering, Construction and Architectural Management 19(1), 101-118.

Mohsan, F., Nawaz, M. M., Khan, M.. S. Shaukat, Z., \& Aslam, N. (2011). Are Employee Motivation, Commitment and Job Involvement Inter-related: Evidence from Banking Sector of Pakistan. International Journal of Business and Social Science 2(17).

Murphy, G., Athanasou, J., \& King, N. (2002). Job satisfaction and organizational citizenship behaviour: A study of Australian human service professionals. Journal of Managerial Psychology 17(4), 287 - 297.

Piercy, N. F., Lane, N., \& Cravens, D. W. (2002). A gender perspective on salesperson organizational citizenship behavior, sales manager control strategy and sales unit effectiveness. Women In Management Review 17(8), 373 - 391.

Rotenberry, P. F., \& Moberg, P. J. (2007). Assessing the impact of job involvement on performance. Management research news, 30(3), 203-215.

Sekaran (2010). Research Methods for Business. Singapore: A John Wiley \& Sons, Ltd, Publication.

Sevi, E. (2010). Effects of organizational citizenship behavior on group performance: Results from an agent-based stimulation model. Journal of Modelling in Management 5(1), 25-37.

Tsai, C. (2008). Leadership style and employee" s job satisfaction in international tourist hotels. Advances in Culture, Tourism and Hospitality Research, 2(2), 293-332.

Turnipseed, D. (1996). Organization citizenship behaviour: an examination of the influence of the workplace. Leadership \& Organization Development Journal, 17(2), $42-47$.

Vignali, C. (1997). Motivation Factors that Force a Sales Training Programme and the Experience within the Brewing Industry. Industrial and Commercial Training, 29(1), 10-15.

Wong, E. S. K., \& Heng, T. N. (2009). Case study of factors influencing jobs satisfaction in two Malaysian universities. International Business Research, 2(2), p86. 